\title{
LOKABASA
}

Jurnal Kajian Bahasa, Sastra, dan Budaya Daerah serta Pengajarannya

Volume 10, No. 1, April - 2019, Hal. 100-107

p-2338-6193 (print) | e-2528-5904 (online)

Homepage: http://ejournal.upi.edu/index.php/lokabasa doi: $10.17509 /$ jlb.v10i1

\section{Kajian Struktur dan Nilai Budaya Cerita Rakyat Palabuhanratu}

\section{Sopudin}

SMP Negeri 1 Cisaat Kabupaten Sukabumi mamangopud@gmail.com

Sejarah Artikel: Diterima (12 September 2018); Diperbaiki (17 November 2018); Disetujui (20 Januari 2019); Pusblished (30 April 2019).

Bagaimana mengutip artikel ini (dalam gaya APA): Kajian Struktur dan Nilai Budaya Cerita Rakyat Palabuhanratu. Lokabasa, 10(1), 1-11. doi: 10.17509/jlb.v10i1.16948

Abstrak: Tujuan dari penelitian ini adalah mendeskripsikan cerita rakyat Palabuhanratu yang merupakan kekayaan intelektual masyarakat Sunda yang keberadaannya semakin tergerus oleh budaya asing. Dengan demikian, perlu upaya nyata untuk menelusuri, mengkaji, dan memperkenalkannya kepada generasi muda, termasuk siswa. Metode penelitian yang digunakan adalah deskriptif-analitis, metode ini digunakan dengan maksud untuk memperoleh gambaran mengenai cerita rakyat Palabuhanratu. Berdasarkan hasil penelitian, dapat digambarkan sebagai berikut. (1) cerita rakyat Palabuhanratu terdiri atas delapan buah; tiga termasuk legenda dan lima termasuk dongeng. (2) Struktur cerita meliputi tokoh dan penokohan, alur, dan latar. Tokoh cerita mulai dari satu orang sampai tujuh orang, bertifikal dinamis dan statis. Cerita semuanya beralur maju dan sederhana, sehingga mudah dipahami. Latar tempat menggambarkan kehidupan tempo dulu, daerah masih berhutan lebat, banyak pohon besar, sungai, dan gunung yang masih belum terjamah oleh manusia. Peristiwa cerita terjadi pada masa lampau, namun tidak disebutkan tanggal, bulan, dan tahun yang pasti. Latar sosial, umumnya tokoh berasal dari lingkungan kerajaan atau bangsawan. (3) Nilai budaya yang ditemukan sebanyak dua puluh lima. Kedua puluh lima nilai budaya tersebut dikelompokkan ke dalam lima bagian, yaitu nilai budaya dalam hubungan manusia dengan Tuhan, nilai budaya dalam hubungan manusia dengan karyanya, nilai budaya dalam hubungan manusia dengan sesamanya, nilai budaya dalam hubungan manusia dengan ruang dan waktu, serta nilai budaya dalam hubungan manusia dengan alam. Nilai-nilai budaya tersebut ada yang masih melekat dalam kehidupan masyarakat sekarang, ada yang telah mengalami pergeseran, dan ada pula yang sudah mengalami perubahan. (4) Cerita rakyat Palabuhanratu dapat dijadikan bahan pembelajaran sastra di sekolah, terutama untuk materi pengayaan.

Kata Kunci: Kajian struktur; cerita rakyat; nilai budaya

\section{The Study of Structure and Culture Values of Pelabuhanratu Folklore}

Abstract: The purpose of this study is to describe Palabuhanratu folklore, intellectual property of the Sundanese people, whose existence is increasingly eroded by foreign cultures. This research employed the descriptive-analytical method. It was employed to obtain an overview of Pelabuhanratu folklore. The results of the study revealed that: (1) Palabuhanratu folklore consists of eight pieces i.e. three legends and five fairy tales. (2) The structure of the story includes the character and characterization, plot, and setting. The story figures amounted from one to seven persons, dynamic and static classification. The story plots are all progressive and simple so that it is easy to understand. The location scene depicts past life, the area is still heavily forested, many large trees, rivers, and mountains that are still untouched by humans. Story events happened in the past, but there are no definite dates, months and years. Generally, the social background of the figures comes from royal or noble family circles. (3) The research found 25 cultural values. The twenty-five cultural values are classified into 5 categories i.e. cultural values of human relations with God, cultural values of human relations with their works, cultural values of human relations with other humans, cultural values of human relations with space and time, and cultural values of human relations with nature. Some of the above cultural values are still inherent in people's lives at the present, some have shifted, and some have undergone changes. (4) Palabuhanratu folklore can be used as a material for literature teaching and learning in schools, especially for enrichment material.

Keywords: Structural studies; folklore; cultural values 


\section{PENDAHULUAN}

Cerita rakyat yang tumbuh dan berkembang di tengah-tengah masyarakat seperti halnya di Jawa Barat umumnya berupa sastra lisan. Jenis sastra ini umumnya dituturkan, didengarkan, dan dihayati secara bersama-sama pada peristiwa tertentu dengan tujuan tertentu pula. Hal ini sesuai dengan yang diungkapkan Rusyana (2000: 207), "Dalam tradisi masyarakat, cerita-cerita itu menggunakan bahasa lisan, yaitu ceritacerita itu dituturkan oleh seseorang kepada yang lainnya, dari generasi tua kepada generasi muda, dan kemudian juga antar sesama warga segenerasi."

Tidak bisa dipungkiri, terutama pada masa lalu di daerah-daerah di Jawa Barat penuturan cerita rakyat dalam bahasa Sunda atau lebih dikenal dengan istilah ngadongéng (bercerita) merupakan tradisi secara turun-temurun. Para orang tua senantiasa menyempatkan diri untuk bercerita (ngadongéng) kepada anakanaknya setiap waktu senggang, terutama menjelang tidur. Begitu pula para nenek dan kakek selalu memanjakan cucucucunya dengan suguhan cerita yang menarik. Keadaan seperti ini terus berlangsung dari satu generasi ke generasi berikutnya, tanpa ada yang mengetahui kapan dimulainya.

Bukan tanpa alasan para orang tua, nenek, dan kakek menyampaikan kisahkisah tertentu kepada orang-orang yang disayanginya. Kisah-kisah tersebut merupakan karya sastra yang sarat dengan makna, sehingga dapat dijadikan sebagai media hiburan dan pendidikan. Hal ini sesuai dengan pendapat Wellek dan Warren (1989: 25), yang mengatakan bahwa sastra berfungsi menghibur, sekaligus mengajarkan sesuatu.

Sangat disayangkan apabila nilai-nilai luhur yang merupakan hasil pemikiran para pendahulu kita harus tergerus oleh roda kemajuan jaman. Saat ini, disadari atau tidak anak-anak baik di lingkungan keluarga maupun di lingkungan sekolah, sudah digiring untuk mengagumi tokohtokoh cerita dari budaya lain. Hal ini diperparah lagi dengan menjamurnya media bacaan dan media elektronik yang dijadikan sarana untuk menggandrungi halhal tertentu oleh anak-anak, seperti aneka tayangan film, acara TV, musik, buku, komik, internet, dan game yang tanpa kita sadari belum tentu sesuai dengan perkembangan usia mereka dan selaras dengan nilai-nilai yang ingin disampaikan orangtua kepada anaknya.

Sementara itu, di lingkungan pendidikan para guru yang senantiasa mewariskan nilai-nilai budaya melalui proses belajar mengajar yang diembannya banyak yang mengalami kesulitan dalam menentukan jenis cerita yang berasal dari daerah tempat bertugas, baik sebagai bahan ajar utama maupun materi pengayaan. Hampir dipastikan semua guru hanya menggunakan materi yang tertera pada buku yang dijadikan acuan, termasuk cerita rakyat. Ini disebabkan minimnya bukubuku pelajaran atau pun buku penunjang yang menyajikan cerita-cerita dari daerah masing-masing. Begitu pula, hasil-hasil penelitian jarang sekali yang dipublikasikan sampai ke perpustakaan sekolah. Padahal, salah satu cara untuk memperkenalkan nilai-nilai luhur bangsa adalah dengan memperkenalkan budaya lokal kepada siswa. Nilai-nilai budaya lokal ini adalah jiwa dari kebudayaan lokal dan menjadi dasar dari segenap wujud kebudayaan di daerahnya.

Berdasarkan hal tersebut di atas, maka penulis merasa perlu untuk mengadakan penelitian yang mengangkat cerita rakyat dari daerah Palabuhanratu dan yang berkaitan dengan daerah Palabuhanratu sebagai materi pengayaan mata pelajaran muatan lokal Bahasa Sunda di SMP. Hal ini dilakukan untuk mengantisipasi kurangnya materi pengayaan yang berupa cerita yang relevan dengan kebutuhan siswa di lingkungan Kabupaten Sukabumi.

Adapun tujuan dalam penelitian ini adalah untuk memperoleh gambaran 
tentang (1) cerita rakyat Palabuhanratu, (2) struktur cerita rakyat Palabuhanratu (3) nilai-nilai budaya dalam cerita rakyat Palabuhanratu, (4) kemungkinan cerita rakyat Palabuhanratu dijadikan materi pengayaan pembelajaran mata pelajaran muatan lokal Bahasa Sunda siswa SMP.

\section{METODE}

Dalam penelitian ini digunakan metode deskriptif-analitis. Metode ini digunakan dengan maksud untuk memperoleh gambaran mengenai cerita rakyat Palabuhanratu saat penelitian dilaksanakan. Dengan menggunakan metode deskriptifanalitis, penelitian tidak terbatas hanya pada pengumpulan dan penyusunan data, tetapi meliputi analisis dan interpretasi tentang makna data tersebut. Dalam pelaksanaanya, data berupa cerita rakyat yang dikumpulkan melalui penelitian dikaji strukturnya. Struktur cerita rakyat kemudian dianalisis untuk diketahui hubungannya dengan unsur-unsur pembentuknya. Selanjutnya, struktur tersebut dihubungkan dan dan dilihat pengaruhnya terhadap manusia sebagai pelaku, fungsi, dan nilai budayanya.

\section{HASIL DAN PEMBAHASAN}

\section{Klasifikasi Cerita}

Cerita rakyat yang isinya berkaitan langsung dengan daerah Palabuhanratu dan sekitarnya, berhasil dikumpulkan penulis dalam penelitian ini sebanyak delapan cerita. Kesemua cerita tersebut masih menyebar dan diketahui masyarakat pemiliknya. Apabila diklasifikasikan berdasarkan jenisnya sesuai dengan pendapat Bascom seperti yang dikutip Danandjaya (2007: 50), maka diketahui ada tiga cerita termasuk golongan legenda (sasakala), yaitu Legenda Palabuhanratu (LP), Sasakala Cisolok (SC), dan Sasakala Batu Kendit (SBK), lima cerita termasuk golongan dongeng, yaitu Putri Kadita (PK), Putri Mayang Cinde (PMC), Putri Mayang
Sagara (PMS), Lebak Cawene (LC), dan Labuh Saji (LS).

\section{Hubungan Cerita dengan Lingkungannya}

Cerita rakyat Palabuhanratu sangat erat hubungannya dengan lingkungan, baik lingkungan masyarakat maupun lingkungan alam. Dalam hubungannya dengan masyarakat sekitar, cerita rakyat mempengaruhi tingkah laku dalam kehidupan sehari-hari. Dengan demikian, cerita bukan hanya sekedar untuk didengarkan, tetapi dianggap benar-benar terjadi.

Pengaruh cerita terhadap tingkah laku kehidupan sehari-hari seperti pada cerita Putri Kadita. Sebagian masyarakat sekitar Palabuhanratu mempercayai adanya kehidupan di alam lain di dasar laut, yaitu suatu kerajaan yang dipimpin oleh seorang ratu yang bernama Putri Kadita. Selain itu, cerita tentang kegiatan upacara labuh saji juga melekat dalam kehidupan masyarakat. Sampai saat ini masyarakat Palabuhanratu, khususnya para nelayan senantiasa melaksanakan upacara labuh saji setahun sekali. Walaupun rangkaian kegiatan dan barang-barang yang diperlukan dalam kegiatan upacara mengalami perubahan sejalan dengan perkembangan jaman.

Cerita rakyat Palabuhanratu juga tidak dapat dilepaskan dari hubungan dengan lingkungan alamnya. Ini terbukti dengan nama-nama tempat yang berkaitan erat dengan cerita yang dituturkan. Sebagai contoh dinamakannya arca Sembah Jayadipati, kampung Cidadap, dan nama Palabuhanratu berkaitan erat dengan cerita Legenda Palabuhanratu. Begitu pula dengan adanya nama sekolah dasar Purnamasari. Masyarakat menganggap bahwa cerita Legenda Palabuhanratu benarbenar terjadi, sehingga untuk mengabadikannya diambillah nama tokoh utama untuk dijadikan nama sebuah sekolah. 
Dalam hubungannya dengan lingkungan alam, juga terjadi dengan penamaan tempat dalam cerita lain. Penamaan tempat Kidang Kancana dan Cangehgar juga erat kaitannya dengan cerita Labuh Saji. Tempat itu diperkirakan merupakan tempat dilaksanakannya kegiatan upacara Labuh Saji kala itu. Dinamakan Kidang karena saat itu dalam rangkaian upacara Labuh Saji selalu ada acara memotong kidang (kijang) sepasang yang telah dipilih ukuran maupun jenis kelaminnya.

Cerita Sasakala Cisolok dan cerita sasakala Batu Kendit pun erat kaitannya dengan penamaan tempat dan barang. Dalam cerita Sasakala Cisolok terdapat beberapa nama yang erat kaitannya dengan isi cerita, seperti gunung Cabe, Karang Hawu, Nambo, dan Cisolok. Adapun cerita sasakala Batu Kendit, erat kaitannya dengan nama sebuah batu yang dinamakan Batu Kendit yang berasal dari nama tokoh cerita yaitu Putri Kendita. Sementara itu, dari cerita Lebak Cawene, dikenal namanama daerah seperti Gunung Bengbreng dan Lebak Cawene.

Untuk mengetahui struktur cerita rakyat Palabuhanratu dilakukan pengkajian terhadap cerita-cerita yang berhasil dikumpulkan. Struktur cerita rakyat Palabuhanratu yang dimaksud adalah (1) tokoh dan penokohan; (2) alur; (3) latar; dan (4) tema. Di samping itu, juga dilakukan pengkajian terhadap nilai budaya yang terkandung dalam cerita.

Tokoh-tokoh cerita dalam CRP berkisar antara satu sampai dengan lima tokoh. Tokoh tersebut ada yang berwujud manusia dan ada pula yang berwujud bukan manusia (makhluk halus). Temuan ini sesuai dengan yang diungkapkan Sudjiman (1992: 16), bahwa tokoh cerita pada umumnya berwujud manusia, tetapi dapat juga berwujud binatang atau benda yang diinsankan. Apabila dilihat dari jenis kelamin, tokoh-tokoh dalam cerita rakyat Palabuhanratu terdiri atas laki-laki, perempuan, dan tidak diungkapkan jenis kelaminnya. Seandainya ditelusuri lebih lanjut, para tokoh dalam cerita rakyat Palabuhanratu umumnya berasal dari golongan bangsawan dan keluarga raja.

Bertitik tolak dari delapan cerita rakyat yang dianalisis, tokoh cerita berjumlah 36 orang. Apabila diklasifikasikan berdasarkan jenis kelamin, terdiri atas 20 orang laki-laki, 14 orang perempuan, satu orang tidak tergambar dengan jelas lakilaki atau perempuan, dan satu tokoh terdiri atas perempuan dan laki-laki.

Apabila ditelusuri lebih lanjut, tokoh utama dalam cerita yang dikaji terdapat 8 orang termasuk tokoh utama, dan 28 orang termasuk tokoh tambahan. Sementara itu, dari delapan tokoh utama, 7 orang berjenis kelamin perempuan dan 1 orang berjenis kelamin laki-laki.

Pencipta cerita rakyat yang dikaji, tentu memiliki tujuan khusus dengan mengedepankan tokoh utamanya yaitu perempuan. Apabila dihubungkan dengan konteks kehidupan masyarakat Sunda, seorang ibu (perempuan) sangat besar. Seorang ibu bertugas sebagai pembimbing anak-anak, sebagai pengatur ekonomi rumah tangga, dan pemdamping serta pendorong bagi kemajuan suaminya. Dengan demikian, dalam konsep pemikiran orang Sunda, kedudukan seorang ibu atau perempuan sangat dihormati.

Apabila ditelaah lebih mendalam, konsep pemikiran orang Sunda tidak bertentangan dengan konsep pemikiran Islam. Dalam konsep Islam dikenal bahwa negara sangat bergantung kepada kaum wanita. Seandainya kaum wanitanya sholihah (baik), maka negaranya pun akan baik. Sebaliknya, seandainya wanitanya thalihah (jelek), maka negaranya pun akan hancur. Hal ini dipertegas dengan sabda Nabi Muhammad SAW, yang mengatakan bahwa dunia ini adalah perhiasan dan sebaik-baiknya perhiasan adalah wanita sholehah (H.R. Muslim).

Selain diklasifikasikan berdasarkan jenis kelamin, tokoh cerita juga dibedakan ke dalam tokoh yang mempunyai watak 
baik dan tokoh yang mempunyai watak jahat. Hal ini menggambarkan bahwa dalam kehidupan masyarakat nyata, karakter manusia itu berbeda-beda. Oleh karena itu, dalam menjalani kehidupan harus senantiasa berhati-hati.

Dalam cerita yang dianalisis, juga tergambar bahwa manusia itu ada yang mengalami perkembangan karakter. Perubahan karakter atau sifat ini lebih banyak diakibatkan pengaruh situasi dan kondisi lingkungan sekitarnya. Dengan demikian, manusia sewaktu-waktu dapat berubah.

Dalam konteks kehidupan masyarakat Sunda, para leluhur Sunda telah mengingatkan hal ini lewat berbagai hal, salah satunya lewat ungkapan, baik babasan maupun paribasa. Para leluhur Sunda tersebut sudah mengingatkan dengan nada teguran, larangan, perintah, atau pun himbauan. Melalui peribahasa akan dapat dipahami pandangan hidup orang Sunda yang menganjurkan agar hidup rukun, mendahulukan kebersamaan, mempunyai pertimbangan yang adil, mempunyai pandangan ke depan sehingga selalu siap kalau pada suatu waktu menghadapi kesulitan, harus menyesuaikan diri dengan lingkungan yang baru, harus bijaksana sehingga dapat mencapai hasil tanpa menimbulkan ketegangan atau kekeruhan, suka tolong-menolong, hemat serta pandai mengatur rizki, tahu diri, tahu aturan, kalau berkata tidak sembarang sehingga tak mudah berubah-ubah, sabar dan tekun dalam mengerjakan sesuatu dan lain-lain.

Hal lain yang perlu diungkapkan berkaitan dengan tokoh cerita dari delapan cerita rakyat yang dianalisis adalah asalusul tokoh. Dari delapan cerita terdapat enam cerita yang pelakunya atau tokohnya berasal dari Kerajaan Pajajaran. Satu cerita berasal dari kerajaan bawahan Pajajaran, dan satu lagi berasal dari luar Pajajaran. Menurut hemat peneliti, para leluhur pencipta cerita ingin menggambarkan bahwa tanah yang didiaminya yaitu Sunda merupakan tanah yang subur makmur.
Selain itu, mereka menginginkan agar galeuh Pajajaran tetap hidup di hati orang Sunda.

Seandainya dihubungkan antara satu cerita dengan cerita lainnya, tentu ada hal yang sangat menarik. Menurut pandangan peneliti, para leluhur pencipta cerita menghendaki agar anak-cucunya menjaga keseimbangan alam antara daratan, hutan, air, dan kehidupan masyarakat. Hal ini ditandai dengan cerita Putri Kadita yang keluar dari Pakuan Pajajaran dan akhirnya membangun kerajaan di dasar lautan. Sementara itu, Prabu Siliwangi yang menghindari serangan Kerajaan Banten memilih tempat di Nusa Larang. Adapun Nyai Putri Gandrung Arum, Putri Prabu Siliwangi memilih menempati sebuah lembah yang masih berupa hutan lebat yang kemudian hari dikenal dengan nama Lebak Cawene. Nyai Putri Purnamasari dan putrinya, Nyai Putri Mayang Sagara berhasil membangun daerah Cidadap dan Panglabuhanratu (sekarang Palabuhanratu). Ini menggambarkan bahwa kehidupan akan subur makmur seandainya manusia bisa menjaga keseimbangan alam antara laut (air) dan daratan (termasuk hutan).

Latar yang digunakan dalam cerita rakyat Palabuhanratu meliputi nama-nama tempat, waktu, dan sosial. Temuan ini sesuai dengan pendapat Nurgiantoro (2010: 227) yang membagi unsur latar ke dalam tiga unsur pokok, yaitu tempat, waktu, dan sosial. Berkaitan dengan latar tempat, banyak sekali tempat yang diungkapkan oleh penutur dalam cerita tersebut, baik berupa keraton, nama daerah, gunung, sungai, pesisir, dan laut. Adapun latar yang berkaitan dengan waktu, tidak ditemukan dalam cerita yang menyebutkan tanggal, bulan, dan tahun secara pasti. Sementara latar sosial yang tergambar hanyalah asalusul para tokoh, umumnya berasal dari kalangan bangsawan dan keluarga raja.

Alur dalam cerita rakyat Palabuhanratu umumnya beralur maju, sederhana, dan mudah dipahami. Peristiwa demi peristiwa yang terjadi dalam cerita bergerak sesuai 
dengan perjalanan waktu, diungkapkan secara jelas, dan kronologis. Dengan demikian, ada keterkaitan antara peristiwa yang satu dengan peristiwa lainnya yang menyebabkan adanya keterjalinan hubungan sebab akibat. Temuan ini sesuai dengan pendapat Nurgiantoro (2010: 153), yang memaparkan bahwa alur terbagi menjadi tiga macam, yaitu alur maju, alur mundur, dan alur campuran.

Tema yang terungkap dalam CRP berkisar antara pertentangan antara kebaikan dan keburukan. Pertentangan ini senantiasa dimenangkan oleh nilai kebaikan. Namun, kebaikan akan berhasil mengalahkan keburukan dengan perjuangan yang didasari ketabahan dan kesabaran.

Nilai-nilai budaya yang ditemukan dalam cerita rakyat Palabuhanratu dikelompokan ke dalam lima bagian. Pertama, nilai budaya dalam hubungan manusia dengan Tuhan. Kedua, nilai budaya dalam hubungan manusia dengan karyanya. Ketiga, nilai budaya dalam hubungan manusia dengan sesamanya. Keempat, nilai budaya dalam hubungan manusia dengan ruang dan waktu. Kelima, nilai budaya dalam hubungan manusia dengan alam.

Nilai-nilai budaya atau biasa disebut juga nilai-nilai kearifan lokal masyarakat Sunda yang tercermin dalam cerita rakyat, apabila dihubungkan dengan kehidupan masyarakat saat ini tentu ada yang tetap dan ada yang mengalami pergeseran. Nilai-nilai budaya yang tetap, di antaranya nilai menyerah pada takdir, nilai kesabaran dan ketabahan, nilai kesetiaan dan kepatuhan, nilai kemauan keras, nilai keberanian, nilai kecerdikan dan kebijakan, nilai bertanggung jawab, nilai kewaspadaan, nilai kejujuran, nilai suka menolong, nilai menghargai pendapat orang lain, nilai harga diri, nilai musyawarah untuk mufakat, nilai suka memaafkan, nilai mempertahankan sistem kekerabatan, nilai mengasihi, nilai menjalin persahabatan, nilai suka bergotong royong, nilai memanfaatkan waktu, dan nilai memanfaatkan alam. Walaupun demikian, bentuk tindakan yang dilakukan masyarakat Sunda yang terdapat dalam cerita akan berbeda dengan keadaan masyarakat pada dunia nyata. Apalagi seandainya dibandingkan dengan kehidupan masyarakat saat ini.

Nilai budaya yang mengalami pergeseran, di antaranya kepercayaan terhadap Tuhan Yang Maha Kuasa, kepercayaan pada roh halus, suka mengembara, suka bertapa, dan penyatuan dengan alam. Kepercayaan terhadap Tuhan Yang Maha Kuasa dan kepercayaan pada roh halus, saat ini bergeser kepada keyakinan terhadap Tuhan Yang Maha Esa melalui agama. Nilai suka mengembara dalam cerita dilakukan dengan tujuan mencari pengalaman, menambah ilmu pengetahuan dan keterampilan, saat ini bergeser selain mencari ilmu juga bertujuan meningkatkan taraf hidup. Hal ini dibuktikan dengan banyaknya anggota masyarakat yang mencari nafkah ke daerah lain, bahkan ke negara lain.

Sementara itu, nilai suka bertapa dan penyatuan dengan alam, dalam cerita dilakukan dengan tujuan mendekatkan diri dengan Yang Maha Kuasa. Biasanya seseorang yang melakukan kegiatan ini menghendaki dikabulkannya sesuatu yang diinginkannya. Nilai ini bergeser kepada kegiatan mendekatkan diri kepada Yang Maha Esa dengan cara beritikap di mesjid, berdzikir, dan bermuhasabah kepada Allah SWT.

\section{Cerita Rakyat Palabuhanratu dapat Dijadikan Materi Pengayaan}

Pengkajian cerita rakyat Palabuhanratu berdasarkan struktur dan nilai budaya dengan menggunakan metode deskriptifanalitis, tidak berhenti begitu saja. Hal ini perlu ditindaklanjuti dengan menawarkan beragam cerita rakyat Palabuhanratu untuk dijadikan materi pengayaan, khususnya mata pelajaran bahasa Sunda di SMP. Materi ini tentu saja disesuaikan dengan kurikulum yang berlaku, agar pemanfaatan- 
nya sesuai dengan yang diharapkan. Di samping itu, materi ini dapat dijadikan sebagai sarana untuk mengenalkan budaya lokal kepada siswa, atau menurut istilah Suherman dan Nugraha (2019, hlm. 348) sebagai kegiatan literasi budaya.

Seandainya ditelusuri cerita rakyat akan banyak memberikan manfaat kepada siswa atau anak yang menyimak atau membacanya. Manfaat yang bisa langsung dirasakan tersebut sebagai berikut

1. Siswa akan memperoleh kesenangan dan mendapatkan kenikmatan ketika membaca atau mendengarkan cerita.

2. Siswa dapat mengembangkan imajinasinya.

3. Siswa memperoleh pengalaman yang luar biasa.

4. Siswa dapat mengembangkan intelektualnya.

5. Siswa akan meningkat kemampuan berbahasanya.

6. Siswa akan lebih memahami kehidupan sosial.

7. Siswa akan memahami nilai keindahan.

8. Siswa akan mengenal budaya.

Dari penjabaran hal di atas, maka cerita rakyat Palabuhanratu, layak diberikan kepada siswa. Salah satunya melalui mata pelajaran muatan lokal Bahasa Sunda.

\section{SIMPULAN}

Berdasarkan pengkajian terhadap struktur dan nilai-nilai budaya yang terkandung dalam cerita rakyat Palabuhanratu (CRP), maka diperoleh kesimpulan sebagai berikut

Pertama, CRP yang berhasil ditranskripsi dan diterjemahkan sebanyak delapan cerita. Setelah diklasifikasikan berdasarkan jenisnya, tiga buah termasuk legenda dan lima buah termasuk dongeng. Ketiga cerita yang berbentuk legenda, yaitu Legenda Palabuhanratu, Sasakala Batu Kendit, dan Sasakala Cisolok. Sedangkan yang berbentuk dongeng, yaitu Putri Mayang Cinde, Putri Kadita, Putri Mayang Sagara, Lebak Cawene, dan Labuh Saji.
Kedelapan cerita itu semuanya dianalisis, baik struktur maupun nilai-nilai budayanya.

Kedua, CRP memiliki struktur sebagai unsur pembentuknya yaitu tokoh dan penokohan, alur, dan tema. Tokoh-tokoh cerita dalam CRP berkisar antara satu sampai lima tokoh. Tokoh tersebut ada yang berwujud manusia dan ada pula yang berwujud bukan manusia (makhluk halus). Latar yang digunakan dalam CRP meliputi nama-nama tempat, waktu, dan sosial. Ketiga latar ini diungkapkan untuk memperjelas berbagai peristiwa yang dialami tokoh-tokoh cerita yang berkaitan dengan tempat dan waktu terjadinya peristiwa tersebut. Sedangkan latar sosial berkaitan dengan asal-usul status sosial tokoh dalam cerita. Alur dalam CRP umumnya beralur maju, sederhana, dan mudah dipahami. Peristiwa demi peristiwa yang terjadi dalam cerita bergerak sesuai sesuai dengan perjalanan waktu, diungkapkan secara jelas, dan kronologis. Dengan demikian, ada keterkaitan antara peristiwa yang satu dengan peristiwa lainnya yang menyebabkan adanya keterjalinan hubungan sebab akibat. Tema yang terungkap dalam CRP berkisar antara pertentangan antara kebaikan dan keburukan. Pertentangan ini senantiasa dimenangkan oleh kebaikan. Namun, kebaikan akan berhasil mengalahkan keburukan dengan perjuangan yang didasari ketabahan dan kesabaran.

Ketiga, nilai-nilai budaya yang ditemukan dalam CRP sebanyak dua puluh lima. Nilai-nilai budaya itu dapat dikelompokan ke dalam lima bagian. Pertama, nilai budaya dalam hubungan manusia dengan Tuhan, meliputi mempercayai bahwa Tuhan Yang Maha Kuasa, menyerah pada takdir, dan keyakinan terhadap roh halus. Kedua, nilai budaya dalam hubungan manusia dengan karyanya, meliputi kesabaran dan ketabahan, kesetiaan atau kepatuhan, kemauan keras, keberanian, kecerdikan dan kebijakan, bertanggung jawab, kejujuran, dan kewaspadaan. Ketiga, nilai budaya 
dalam hubungan manusia dengan sesamanya, meliputi suka menolong, menghargai pendapat orang lain, harga diri, musyawarah untuk mufakat, suka memaafkan, mempertahankan sistem kekerabatan, nilai menjalin persahabatan, nilai suka bergotong royong, dan mengasihi. Keempat, nilai budaya dalam hubungan manusia dengan ruang dan waktu, meliputi sikap suka mengembara, nilai suka bertapa, dan memanfaatkan waktu. Kelima, nilai budaya dalam hubungan manusia dengan alam, suka bertapa, meliputi penyatuan dengan alam dan memanfaatkan alam. Nilai-nilai budaya yang terdapat di dalam CRP umumnya masih berlaku dan diwariskan kepada generasi yang lebih muda. Dari dua puluh lima nilai budaya, dua puluh tiga nilai budaya masih ditemukan di lingkungan masyarakat pemilik cerita ini. Dengan demikian, hanya tiga nilai yang kurang nampak dalam kehidupan sehari-hari, yaitu nilai suka mengembara, nilai suka bertapa, dan nilai penyatuan dengan alam.

Keempat, cerita rakyat Palabuhanratu layak dijadikan materi pengayaan mata pelajaran muatan lokal bahasa Sunda di SMP.

\section{UCAPAN TERIMA KASIH}

Penulis mengucapkan terima kasih kepada semua pihak yang telah membantu penelitian ini dengan tulus. Terima kasih pula penulis sampaikan kepada pengelola jurnal yang telah menerbitkan artikel hasil penelitian ini. Semoga Allah melimpahkan balasan yang tiada terhingga, amin.

\section{CATATAN PENULIS}

Penulis menyatakan bahwa tidak ada konflik kepentingan terkait publikasi artikel ini. Penulis mengkonfirmasi bahwa data dan artikel ini bebas plagiarisme.

\section{PUSTAKA RUJUKAN}

Danandjaja, J. (2007). Foklor Indonesia (Ilmu Gosif, Dongeng, dan lain-lain). Jakarta: Pustaka Utama Grafiti.

Nurgiantoro, B. (2010). Teori Pengkajian Fiksi. Yogyakarta: Gadjah Mada Mada University Press.

Rusyana, Y. (2011). "Nilai Budaya dalam Susastra Sunda." Makalah Disajikan dalam Seminar Internasional II FKIP UNSUR Cianjur tanggal 4 Juni 2011.

Sudjiman, P. (1992). Memahami Cerita Rekaan. Jakarta: Pustaka Jaya.

Suherman, A. \& Nugraha, H.S. (2019). Culture and Citizenship Literacy in Sundanese Children's Literature. Dalam A.G. Abdullah \& A.A. Danuwijaya (Peny.). Proceeding Second Conference on Language, Literature, Education, and Culture (ICOLLITE) (hlm, 346-348). Paris: Atlantis Press.

Wellek, R. dan Austin W. (1989). Teori Kesusastraan. Terjemahan Melani Budianta. Jakarta: Gramedia. 